\title{
Anxiety in patients attending dental university clinics
}

\author{
Carla de Souza Oliveira*; Oldeir Digno Ribeiro de Souza**; Alexa Magalhães Dias*; Tuélita Marques \\ Galdino*; Raquel Conceição Ferreira***; Cláudia Silami de Magalhães ${ }^{* * * *}$
}

\author{
* Assistant Professor, Dentistry Department, Federal \\ University of Juiz de Fora \\ ** Graduate in Dentistry, Federal University of Juiz de Fora \\ *** Associate Professor, Department of Social and Preventive \\ Dentistry, Federal University of Minas Gerais \\ **** Full Professor, Department of Restorative Dentistry, Federal \\ University of Minas Gerais
}

Received November 14, 2018. Approved December 23, 2018.

\begin{abstract}
This study aimed to investigate anxiety in patients attended at a university dental clinic. The present cross-sectional study included 49 patients recruited at the undergraduate dental clinics, Federal University of Juiz de Fora, Governador Valadares campus, Minas Gerais, Brazil, from September 2016 to August 2017. Information regarding gender, age, family income, educational level, frequency of dental consultations and dental procedure causing discomfort were collected using a questionnaire. The level of anxiety was evaluated by the Dental Anxiety Scale. A mild level of anxiety (median=6) was observed, with a minimum level of 4 (not anxious) and a maximum level of 19 (extremely anxious). Women had higher anxiety than men $(\mathrm{p}=0.047)$. Individuals with $9-11$ years of schooling presented a lower level of dental anxiety than those with $0-8$ years of schooling $(\mathrm{p}=0.025)$. Participants who attributed a greater discomfort to surgeries and the use of high-speed burs had a greater anxiety $(\mathrm{p}=0.002)$. Light anxiety is present in patients undergoing dental treatment in university clinics, and women are more anxious than men. Patients with higher education were less anxious than lower education level. The report of a greater discomfort with surgeries and procedures with high-speed burs were associated with a greater anxiety.
\end{abstract}

Descriptors: Dental Anxiety. Dental Care. Dental Clinics. Oral Health.

\section{INTRODUCTION}

Dental anxiety is an event that occurs due to a treatment or a perspective of dental treatment capable of generating a feeling of distress or fear. Its intensity varies according to patient or in the same patient depending on the dental procedure ${ }^{1}$. 
This condition is considered multifactorial, and may be related to traumatic experiences by the individual himself or passed on by others, or psychological traits ${ }^{2,3}$.

Anxiety, excitement, and fear generated by dental procedures may be a barrier to maintaining oral health ${ }^{1,4}$. Despite advances in pain control, moderate or severe dental anxiety manifests in 2 out of 8 Brazilians, being an obstacle and leading to the avoidance of dental care for part of the population $^{5}$.

High rates of dental anxiety among the elderly population (65 years or older) were associated with worse oral health conditions, such as a greater number of root remains, lower frequency of visits to the dentist and problemmotivated dental visits ${ }^{6}$. Avoidance of consultations, increased dental caries and reduction in quality of life related to oral health are some fear and dental anxiety reflexes to the affected individuals lives ${ }^{2}$. Patients with a history of dental treatment anxiety may also present negative thoughts and feelings, sleep disturbances, increased medication use and a greater tendency to somatization, impairing social interaction. Thus, this may be considered a public health problem ${ }^{7}$.

There are studies suggesting that pretreatment anxiety increases the chances of developing post-traumatic stress following dental treatment ${ }^{8}$. The opposite may also occur: groups of individuals with dental anxiety reported having experienced previous traumatic experiences, thus suggesting that such experiences may play a significant role in the development of dental anxiety ${ }^{9}$. Pre-treatment anxiety and the associated stress response may lead to increased pain sensation, treatment complications, inhibit or delay optimal recovery, and further increase post-treatment pain ${ }^{10}$.

The investigation of anxiety levels of patients before dental treatment represents an important strategy that should be taken into account in preventive and curative programs in search for a better integration to and patient involvement with the maintenance process of oral health ${ }^{4}$.

Knowing the patients' profile regarding the fear or anxiety generated by dental treatment allows the institution of methods to avoid or ameliorate such feelings, paralyzing or not allowing the trauma of dental consultations.

This study aims to investigate the anxiety level of patients attended at undergraduate dental clinics using the dental anxiety scale and a socioeconomic questionnaire. It also aims to correlate the level of dental anxiety with schooling, income, age, sex, frequency of dental consultations and dental procedure causing discomfort.

\section{MATERIAL AND METHODS}

This was a cross-sectional observational study involving patients attending the undergraduate dental clinics of the Federal University of Juiz de Fora, Governador Valadares campus, Minas Gerais, Brazil, from September 2016 to August 2017. Subjects were recruited by convenience using the nonprobabilistic sampling technique. The inclusion criteria were: 18 years of age or older, and literate individuals able to understand and communicate in order to answer questions. This research was approved by the Research Ethics Committee of the Federal University of Juiz de Fora (CAAE no. 55794616.4.0000.5147). All individuals signed an Informed Consent.

A questionnaire was applied to collect data related to the variables: gender, age, family income, educational level, frequency of dental consultations and dental procedure causing discomfort $^{9}$. The assessment of the level of anxiety was performed using the scale of Corah: Dental Anxiety Scale (DAS) ${ }^{11}$, translated and 
validated by $\mathrm{Hu}$ et $a l .{ }^{12}$, ranging from 4 to 20 points according to table 1. Participants answered the questionnaires in the dental clinics waiting room, before attendance, to avoid a bias of response due to embarrassment. The researchers that applied the questionnaires were previously trained and were present to clarify possible doubts.

Table 1. Classification of dental anxiety level according to Corah scale (DAS) (CORAH, 1969) ${ }^{11}$

\begin{tabular}{cc}
\hline ANXIETY LEVEL & POINTS \\
\hline Not anxious & up to 5 points \\
Slightly anxious & 6 to 10 points \\
Fairly anxious & 11 to 15 points \\
Extremely anxious & 16 to 20 points \\
\hline
\end{tabular}

The data obtained were elaborated and analyzed by the SPSS 20.0 software. A descriptive analysis of the data was performed, and the Shapiro-Wilk adherence test was applied to verify normality. Upon verifying nonnormality, Mann Whitney and Kruskal-Wallis tests were used with a significance level of 5\% for the association of dental anxiety with the variables gender, age group, education level, monthly family income, visits to the dentist and procedure causing discomfort.

\section{RESULTS}

The sample consisted of 50 patients. A patient who did not answer the questionnaire corresponding to the Corah scale (DAS) was excluded $^{11}$. Forty-nine subjects were included in the analysis, of which 20 were women and 26 men (three patients did not report gender). The most prevalent age group was 36-54 years (46.9\%), $42.6 \%$ had $0-8$ years of schooling and $23.4 \%$ had more than 12 years of schooling. The majority reported a monthly family income below one minimum wage $(87.2 \%)$. Table 2 presents the sociodemographic characterization of the participants.

Twenty participants (40.8\%) reported seeking dental care only when they felt pain, while $16(32.7 \%)$ sought dental care with a frequency of 6-12 months (table 2).

The procedures that use high rotation were the most indicated as causing discomfort to patients (28.3\%), followed by anesthesia (19.6\%) (table 2).

According to the Corah scale ${ }^{11}$ the median of anxiety 6 indicated a slightly anxious level, with a minimum of 4 (not anxious) and a maximum of 19 points (extremely anxious). Women were more likely to have dental anxiety than men ( $\mathrm{p}=0.047)$. In addition, females presented a maximum point value of 19 (extremely anxious), while the maximum male value was 10 points, which corresponds to slightly anxious.

The patient's age $(\mathrm{p}=0.178)$, income $(\mathrm{p}=0.370)$ and frequency of dental consultations $(p=0.484)$ did not significantly affect anxiety. The level of education significantly influenced the level of anxiety ( $\mathrm{p}=0.025)$. Individuals with 9-11 years of schooling presented a lower level of dental anxiety (median 4 ) than those with $0-8$ years of schooling (median 8) (table 3).

There was a significant difference in the level of anxiety related to the most uncomfortable dental procedures $(\mathrm{p}=0.003)$. Participants who reported a greater discomfort to surgeries and the use of 
high-speed burs had a greater anxiety (table 3).

\section{DISCUSSION}

The anxiety generated by dental treatment is a recurring theme in the clinical practice of dentist surgeons. This may lead to a difficulty or even a failure of procedures, since anxiety may interfere with the patient's engagement and commitment to the continuity of treatment.

In this study, the sample was classified as mildly anxious, in disagreement with the study by Chaves et al. (2006) ${ }^{4}$, on patients attended at another undergraduate clinic, where the majority presented moderate and exacerbated levels of anxiety. A reduced dental anxiety in the present study may be due to a current improvement in the quality of dental treatments, with reduced pain, less invasive procedures and better communication between the dental team and the patient ${ }^{13}$. The way patients behave in face of treatment reflects the way the dental surgeon and its team treat the patients ${ }^{14}$. A decrease in fear has been observed over the years in a longitudinal study in Finland, where patients were more fearful of dental treatment in 2000 than in $2011^{15}$.

About $40 \%$ of the participants reported seeking dental care when they felt pain. A similar result was previously observed with $3.3 \%$ of patients reported returning to the dentist every 6 months, and $40 \%$ sought care only in case of pain. ${ }^{4}$ Several factors may explain the pain-induced demand, such as difficulties in accessing dental care and the fear or anxiety generated in the individual before dental appointments. Dental anxiety was considered an important predictor of visits frequency to the dentist ${ }^{16}$.

Table 2. Sample characterization regarding gender, age, educational level, monthly family income, frequency of dental consultations and procedure that causes discomfort

\begin{tabular}{lcc}
\hline Variables & (n) & $\mathbf{( \% )}$ \\
\hline Gender & & \\
Male & 20 & 43,5 \\
Female & 26 & 56,5 \\
Age range & & \\
15-35 years & 16 & 32,7 \\
36-54 years & 23 & 46,9 \\
Z55 years & 10 & 20,4 \\
Educational level & & \\
0-8 years of schooling & 20 & 42,6 \\
9-11 years of schooling & 16 & 34,0 \\
More than 12 years of schooling & 11 & 23,4 \\
Monthly family income & & \\
Less than minimum wage (US\$ 261,00) & 41 & 87,2 \\
$\quad$ More than minimum wage (US\$ 261,00) & 6 & 12,8 \\
Frequency of dental consultations & & \\
Often (6-12 months) & 16 & 32,7 \\
Only when they felt pain & 20 & 40,8 \\
$\quad$ Don't remember & 13 & 26,5 \\
Procedure that causes discomfort & & \\
High-speed burs & 13 & 28,3 \\
Anesthesia & 9 & 19,6 \\
Surgeries & 8 & 17,4 \\
$\quad$ Nothing & 16 & 34,8 \\
\hline
\end{tabular}


Table 3. Values of anxiety level, according to Dental Anxiety Scale (DAS) in Median, minimummaximum, and interquartile distance

\begin{tabular}{|c|c|c|c|c|c|}
\hline \multirow[t]{2}{*}{ Variables } & \multirow[b]{2}{*}{ Median } & \multicolumn{4}{|c|}{ ANXIETY LEVEL } \\
\hline & & $\begin{array}{l}\text { Minimum- } \\
\text { Maximum }\end{array}$ & $\begin{array}{c}\text { Interquartile } \\
\text { distance }\end{array}$ & $\begin{array}{c}\mathbf{N} \\
(\%)\end{array}$ & P-value \\
\hline \multicolumn{6}{|l|}{ Gender $^{t}$} \\
\hline Male & 5 & $4-10$ & 3 & $(42,2)$ & $0,047 *$ \\
\hline Female & 7 & $4-19$ & 8 & $(57,8)$ & \\
\hline \multicolumn{6}{|l|}{ Age range $^{\ddagger}$} \\
\hline $15-35$ years & 7 & $4-15$ & 5 & $(33,3)$ & 0,178 \\
\hline $36-54$ years & 4 & $4-19$ & 4 & $(45,8)$ & \\
\hline$\geq 55$ years & 7 & $4-17$ & 7 & $(20,8)$ & \\
\hline \multicolumn{6}{|l|}{ Educational level $^{\ddagger}$} \\
\hline $0-8$ years of schooling & $8^{\mathrm{A}}$ & $4-19$ & 9 & $(43,5)$ & $0,025^{*}$ \\
\hline $9-11$ years of schooling & $4^{\mathrm{B}}$ & $4-9$ & 2 & $(34,8)$ & \\
\hline More than 12 years of schooling & $7^{\mathrm{A}, \mathrm{B}}$ & $4-17$ & 6 & $(21,7)$ & \\
\hline \multicolumn{6}{|l|}{ Monthly family income $e^{t}$} \\
\hline Less than minimum wage (US\$261,00) & 6 & $4-19$ & 6 & $(89,1)$ & 0,370 \\
\hline More than minimum wage (US\$261,00) & 4 & $4-9$ & 4 & $(10,9)$ & \\
\hline \multicolumn{6}{|l|}{ Frequency of dental consultations $s^{\ddagger}$} \\
\hline Often (6-12 months) & 5 & $4-15$ & 4 & $(33,3)$ & 0,484 \\
\hline Only when they felt pain & 6 & $4-17$ & 6 & $(39,6)$ & \\
\hline Don't remember & 7 & $4-19$ & 8 & $(27,1)$ & \\
\hline \multicolumn{6}{|l|}{ Procedure that causes discomfort ${ }^{\ddagger}$} \\
\hline High-speed burs & $7^{\mathrm{A}}$ & $4-19$ & 6 & $(28,9)$ & $0,003 *$ \\
\hline Anesthesia & $5^{\mathrm{A}, \mathrm{B}}$ & $4-17$ & 9 & $(17,8)$ & \\
\hline Surgeries & $7^{\mathrm{A}}$ & $5-11$ & 4 & $(17,8)$ & \\
\hline Nothing & $4^{\mathrm{B}}$ & $4-10$ & 0 & $(35,5)$ & \\
\hline
\end{tabular}

*p $<0,05 \quad{ }^{t}$ Mann-Whitney test ${ }^{\ddagger}$ Kruskal-Wallis test

Medians followed by different letters presented statistically significant differences ( $\mathrm{p}<0.05$; Dunn-Bonferroni test for multiple comparisons)

Patients with a high fear of dental treatment tend to avoid consultations ${ }^{17}$. Data from Brazilian survey, in 2010, showed that for $14.5 \%$ of the population aged 15-19 years, pain was the reason for the last dental appointment. In the age group $35-44$, the percentage was $15.8 \%$, and in the population aged $65-74$ years, it was $8.4 \%$, lower than that found in this study ${ }^{18}$.

The patient's age and income do not have a statistically significant association with the level of dental anxiety. This situation was repeated in other studies addressing these variables ${ }^{4,15,19}$. Nevertheless, younger, more educated individuals with a better income reported a greater dental anxiety and a greater demand for dental care ${ }^{20}$.

Patients with more years of schooling were less anxious than those with less schooling. The same result was observed when the level of dental anxiety of patients attending clinics of the Faculty of Dentistry of a Federal University was investigated. The highest percentage of anxious or very anxious patients was among those with a lower level of education ${ }^{21}$. However, in another study, individuals with a higher education were more fearful of attending the dentist compared to those with primary and secondary education ${ }^{15}$. Results of several studies are contradictory, showing, in the majority, a non-significant association between schooling and dental 
anxiety, or a disagreement between direct or inverse association between these variables. Further studies are needed to evaluate this possible association $^{1,4,15,19}$.

In this study, the level of anxiety and frequency of dental consultations did not present a significant association, but patients with a frequency of 6-12 months consultations were less anxious. A correlation was observed between regular dental care and dental anxiety ${ }^{22}$. Individuals with less regular visits to the dentist have shown an increased anxiety ${ }^{23,24}$. Anxiety was also related to the patients non-attendance at the dental clinic ${ }^{25}$. This fact is worrying because fear can lead to a lower search for dental care, impairing oral health. Another aggravating factor is that people with a greater anxiety about dental treatment showed a poorer oral hygiene compared to those with less anxiety ${ }^{23}$. The individual with dental anxiety or fear may be trapped in a vicious cycle (Berggren Model) in which fear, pain, guilt, and inferiority prevent a proper oral hygiene, as well as the search for treatment ${ }^{26}$.

The female gender was considered the best predictor for dental anxiety ${ }^{13}$. Women were more anxious in this study and in others, whose participants were recruited in different public and undergraduate clinics ${ }^{4,15,19,21,27,28}$. The study that validated the MDAS (Modified Dental Anxiety Scale) anxiety scale, based on the Corah scale, showed that women had a greater dental anxiety in relation to men, with gender explaining $5 \%$ of the variance of dental anxiety ${ }^{24}$.

Participants reported that the dental procedures that most promoted discomfort were surgery and anesthesia. However, dental anxiety was higher in those who reported a greater discomfort with surgeries and use of high-speed burs. These procedures corresponded to $21.7 \%$ of the procedures identified as uncomfortable in the study by Chaves et al. $(2006)^{4}$, with surgery being the main procedure causing trauma ${ }^{21}$.

Individuals with traumatic experiences, mainly related to pain during dental treatment, may relive this situation in future consultations. This may be associated with dental anxiety manifested by them ${ }^{17}$. Previous traumatic patients presented a higher percentage of anxiety to dental treatment ${ }^{21}$. A qualitative study showed that patients with dental anxiety reported having a negative traumatic experience in previous dental treatments, generally related to pain. Adding to this, they did not feel supported by the dentist or its team ${ }^{29}$.

Patients suffering from fear or dental anxiety should be treated according to their anxiety profile with distraction and relaxation methods that fit their needs ${ }^{27}$. These approaches may ease the anxiety generated by dental procedures and bring a greater comfort to the patient, reducing stress and the chances of generating or emphasizing a trauma.

A limitation of this study was the sample size. A larger number of participants could present less variability in the results, highlighting other significant associations. In addition, qualitative studies are required to understand why specific procedures are more uncomfortable than others and how dental care could become less uncomfortable for patients.

This issue should be emphasized on the searching for a humanized and integrated dental practice, as described in the National Curricular Guidelines (2002) for the professional training in dentistry $^{30}$. The patient's experiences may interfere with the success or failure of a treatment, and the dental surgeon must be prepared to act in this scenario.

\section{CONCLUSION}

Anxiety in dental treatment was present, although at a mild level. Women were more anxious than men in the sample studied. 
Individuals with higher education levels were less anxious. Participants who reported surgeries and the use of high-speed burs as the procedures that caused the most discomfort presented a greater anxiety to dental treatment.

\section{RESUMO}

\section{Ansiedade em pacientes atendidos em clínicas odontológicas universitárias}

Este estudo objetivou investigar a ansiedade em pacientes atendidos em clínicas odontológicas universitárias. $\mathrm{O}$ presente estudo transversal incluiu 49 pacientes recrutados nas clínicas odontológicas da Universidade Federal de Juiz de Fora, campus Governador Valadares, Minas Gerais, Brasil, de setembro de 2016 a agosto de 2017. Informações sobre sexo, idade, renda familiar, escolaridade, frequência de consultas odontológicas e procedimentos odontológicos causadores de desconforto foram coletadas por meio de questionário. $\mathrm{O}$ nível de ansiedade foi avaliado pela Dental Anxiety Scale. Observou-se um nível de ansiedade leve (mediana $=6)$, com mínimo de 4 (não ansioso) e máximo de 19 (extremamente ansioso). As mulheres apresentaram maior ansiedade que os homens ( $p$ $=0,047$ ). Indivíduos com 9 a 11 anos de escolaridade apresentaram menor nível de ansiedade odontológica do que aqueles com 0 a 8 anos de estudo ( $\mathrm{p}=0,025)$. Os participantes que atribuíram maior desconforto às cirurgias e ao uso de alta rotação apresentaram maior ansiedade $(\mathrm{p}=0,002)$. Conclui-se que a ansiedade leve está presente em pacientes submetidos a tratamento odontológico em clínicas universitárias, sendo as mulheres mais ansiosas do que os homens. Pacientes com maior grau de instrução foram menos ansiosos. O relato de maior desconforto com cirurgias e procedimentos alta rotação pode estar associado a uma maior ansiedade.

Descritores: Ansiedade ao Tratamento Odontológico. Assistência Odontológica. Clínicas Odontológicas. Saúde Bucal.

\section{REFERENCES}

1. Maniglia-Ferreira C, Gurgel-Filho ED, Bönecker-Valverde G, Moura EH, Deus G,
Coutinho-Filho T. Ansiedade odontológica: nível, prevalência e comportamento. RBPS. 2004; 17(2):51-5.

2. Beaton L, Freeman R, Humphris G. Why Are People Afraid of the Dentist? Observations and Explanations. Med Princ Pract. 2014; 23:295-301.

3. Wolpe, J. The dichotomy between classical conditioned and cognitively learned anxiety. $\mathrm{J}$ Behav Ther Exp Psych. 1981; 12(1):35-42.

4. Chaves AM, Loffredo LCM, Júnior AV, Chavez OM, Campos JADB. Estudo epidemiológico da ansiedade dos pacientes ao tratamento odontológico. Rev Odontol UNESP. 2006; 35(4):263-68.

5. Carvalho RWF, Falcão PGCB, Campos GJL, Bastos AS, Pereira JC, Pereira MAS, et al. Ansiedade frente ao tratamento odontológico: prevalência e fatores preditores em brasileiros. Ciênc Saúde Coletiva. 2012; 17(7):1915-22.

6. Elter JR, Strauss RP, Beck JD. Assessing dental anxiety, dental care use and oral status in older adults. J Am Dent Assoc. 1997; 128:591-7.

7. Gordon D, Heimberg RG, Tellez M, Ismail A. I. A critical review of approaches to the treatment of dental anxiety in adults. J Anxiety Disord. 2013; 27:365-78.

8. Armitage CJ, Reidy JG. Evidence that process simulations reduce anxiety in patients receiving dental treatment: randomized exploratory trial. Anxiety Stress Coping. 2012; 25(2):155-65.

9. Humphris G, King K. The prevalence of dental anxiety across previous distressing experiences. J Anxiety Disord. 2011; 25:232-6.

10. Thoma MV, Zemp M, Kreienbühl L, Hofer D, Schmidlin PR, Attin T, et al. Effects of music listening on pre-treatment anxiety and stress levels in a dental hygiene recall population. Int J Behav Med. 2015; 22:498-05.

11. Corah NL. Development of a Dental Anxiety 
Scale. J Dent Res. 1969; 48:596.

12. Hu LW, Gorenstein C, Fuentes D. Portuguese version of Corah's Dental Anxiety Scale: transcultural adaptation and reliability analysis. Depress Anxiety. 2007; 24(7):467-71.

13. Stenebrand A, Hakeberg M, Nydell Helkimo A, Koch G, Wide Boman U. Dental anxiety and oral health in 15-year-olds: a repeated crosssectional study over 30 years. Community Dent Oral Epidemiol. 2015; 32:221-5.

14. Corah NL, O'Shea RM, Skeels DK. Dentists' perceptions of problem behaviors in patients. $\mathrm{J}$ Am Dent Assoc. 1982; 104:829-33.

15. Liinavuori, A, Tolvanen M, Pohjola V, Lahti S. Changes in dental fear among Finnish adults: a national survey. Community Dent Oral Epidemiol. 2016; 44:128-34.

16. Crocombe LA, Broadbent JM, Thomson WM, Brennan DS, Slade GD, Poulton R. Dental visiting trajectory patterns and their antecedents. J Public Health Dent. 2011; 71:23-31.

17. De Jongh, A, Van Der Burg J,Van Overmeir M, Aartman I, Van Zuuren FJ. Trauma-related sequelae in individuals with a high level of dental anxiety. Does this interfere with treatment outcome? Behav Res Therapy. 2002;40:1017-29.

18. Brasil. Ministério da Saúde. SB BRASIL 2010: Pesquisa Nacional de Saúde Bucal: resultados principais. Brasília, DF; 2012. [Cited July 31, 2018]. Available at: http://bvsms.saude.gov.br/bvs/publicacoes/pe squisa_nacional_saude bucal.pdf.

19. Kanegane K, Penha SS, Borsatti MA, Rocha RG. Ansiedade ao tratamento odontológico e atendimento de urgência. Rev Saúde Pública. 2003; 37(6):786-92.

20. Bernabe E, Humphris G, Freeman R. The social gradient in oral health: Is there a role for dental anxiety? Community Dent Oral
Epidemiol. 2017; 45(4):348-55.

21. Nascimento DL, Araújo ACSA, Gusmão ES, Cimões, R. Anxiety and fear of dental treatment among users of public health services. Oral Health Prev Dent. 2011; 9(4):329-37.

22. Donaldson AN, Everitt B, Newton T, Steele J, Sherriff M, Bower E. The effects of social class and dental attendance on oral health. $\mathbf{J}$ Dent Res. 2008; 87(1):60-4.

23. Donno MA. Dental anxiety, dental visits and oral hygiene practices. Oral Health Prev Dent. 2012; 10(2):129-33.

24. Humphris G, Crawford JR, Hill K, Gilbert A, Freeman R. UK population norms for the modified dental anxiety scale with percentile calculator: adult dental health survey 2009 results. BMC Oral Health. 2013; 13(29):8-11.

25. Skaret E, Raadal M, Kvale G, Berg E. Factors related to missed and cancelled dental appointments among adolescents in Norway. Eur J Oral Sci. 2000;108(3):175-83.

26. Berggren ULF, Meynert G. Dental fear and avoidance: causes, symptoms, and consequences. J Am Dent Assoc. 984; 109:247-51.

27. Litt MD, Kalinowski L, Shafer D. A dental fears typology of oral surgery patients: matching patients to anxiety interventions. Health Psychology 1999; 18(6):614-24.

28. Shuller A A, Willumsen T, Holst, D. Are there differences in oral health behavior between individuals with high and low dental fear? Community Dent Oral Epidemiol. 2003; 31(2):116-21.

29. Abrahamsson KH, Berggren ULF, Hallberg L, Carlsson SG. Dental phobic patients' view of dental anxiety and experiences in dental care: a qualitative study. Scand J Caring Sci. 2002; 16:188-96.

30. Brasil. Ministério da Educação. Conselho Nacional de Educação. Câmara de Educação 
Superior. Resolução CNE-CES n.3. Diretrizes

Curriculares Nacionais do Curso de Graduação em odontologia. Diário Oficial da União, Brasília, 4.mar. 2002. Seção 1. [Cited July 31, 2018]. Available at: http://portal. mec.gov.br/cne/arquivos/pdf/CES032002.pdf.
Correspondence to:

Carla de Souza Oliveira

e-mail: carla.souza@ufjf.edu.br

Av. Sete de Setembro, 1905/202 Esplanada 35010-171 Governador Valadares/MG Brazil 